The suggestion put forward by Mr. MeEvoy, the Town Clerk, in stating the case for the application, was that excavation should proceed under skilled archæological supervision, the cost entailed over and above the normal cost of excavation to be borne by a local committee representing those interested in ancient remains. Against this, Mr. Colin D. R. Elles, the chairman of the excavation committee, handed in a petition, which had been signed by 3,235 persons in four days only, asking that the remains should be preserved; while Mr. Baillie Reynolds not only stated that his department would look with great favour on any scheme to preserve the remains, but also intimated that the Office of Works would co-operate in laying them out to advantage.

\section{Forensic Medicine}

THE Advisory Committee on the Scientific Investigation of Crime, under the chairmanship of Lord Trenchard, recently issued its report (London: H.M. Stationery Office, 1936. 2d. net), from which it would appear that the teaching of forensic medicine in London is in an extremely backward condition as com. pared with the teaching of that subject in most of the capitals of Europe, and well behind the standard set in Scotland. As the Committee points out, this is not confined to the restricted sphere of criminal investigation and police practice, but extends to the study of many problems connected with social medicine and to the whole question of medico-legal practice. The Committee recommends the establishment of a medico-legal institute which would act as a training centre for medico-legal experts and as a centre for special pathological research, and it also suggests that facilities should be given for courses of instruction for students of law, coroners and other persons who are associated with medico-legal work.

As to the question of police laboratories, though in certain circumstances it is no doubt advisable to have laboratory facilities under the direction of the police, the proper place for extensive medico-legal investigations is in connexion with departments of universities. If the investigating authorities are to have the facility of obtaining advice on all kinds of scientific subjects, as they must, there is no possibility of so doing if they are restricted to police laboratories. Such advice and assistance can be obtained only through the universities. It is, however, impossible for the police authorities to know what departments to consult, and therefore a department of forensic medicine within the university offers the only means by which full use of the latest advances in science may be obtained. On considering the whole matter, it would appear to be advisable for the authorities in London to concentrate their efforts in founding a Department of Forensic Medicine in connexion with the University of London, and to make the necessary arrangements for the ample material, which is at present largely wasted, to be utilized in the teaching of elementary forensic medicine to medical students and to offer facilities for postgraduate study and research to those who desire to specialize in this subject.

\section{Technical College Equipment}

WE have received from an Advisory Committee on Technical College Equipment, British Industries House, Marble Arch, London, W.1, a memorandum on a scheme in progress for setting up an exhibition at British Industries House showing the equipment necessary for technical institutions. This movement is designed to help those responsible for expenditure on these centres in view of the very large outlay anticipated during the next few years by the Board of Education. The Committee represents the three associations concerned with technical teaching and also the Institution of Production Engineers, and hence is an authoritative body. It is pointed out that the present method of deciding on a design, that of visiting recent buildings and utilizing the composite information obtained, wastes time and is unsatisfactory. Technical education in Great Britain is lamentably behind that on the Continent in the matter of material equipment and buildings, hence this scheme is to be commended. The relationships of the pieces of mechanism will no doubt be an important part of the Committee's work, though this must be to some extent subservient to the configuration of the floor space. More difficult will be the presentation of the structural features and service supplies essential as the basis of the equipment. It is stated that the object is to enable full information to be obtained for getting out estimates for building, extending, and equipping institutions. So far as the two former functions are concerned, it seems difficult to see how the exhibition can supply any detailed information, from the province of trained professional advisers and necessarily varying with local conditions; such advisers, however, should be able to learn much from the exhibition.

\section{Geological Survey and Museum: New Activities}

A NEw publications stall, where the public may purchase the official guides and geological memoirs, including the series of handbooks on British Regional Geology referred to in NatuRE of September 5 (p. 389), has been opened in the entrance hall of the new Geological Museum at South Kensington. The Museum has also published an extensive series of excellent photographic postcards, price $1 d$. each, which are likely to be of value to teachers of geology and physical geography. The postcards include reproductions of general views of the Museum, with dioramas and other interesting exhibits; and photographs of British localities of geological interest, with explanatory text, illustrating marine erosion and sea coasts, rock-weathering and denudation, vulcanism, glaciation, and similar subjects. A list is obtainable from the Museum. An experimental series of free public lantern lectures and lecture tours on the geology and scenery of various regions of Great Britain was given last month. The lectures were well attended, and will be continued throughout the winter. Facilities for special parties can be arranged. Recent additions to the exhibited collections include a series of specimens from H.M. Office of Works, illustrating the weathering of the building stone 